\title{
Infrastructure Budget and Poverty Reduction in Indonesia 2016
}

\author{
Nur Ambia Arma \\ Student of Faculty of Public \\ Administration \\ Brawijaya University \\ Malang, Indonesia \\ ambiaarma.aa@gmail.com
}

\author{
Irwan Noor \\ Lecturer of Faculty of Public \\ Administration \\ Brawijaya University \\ Malang, Indonesia
}

\author{
Sujarwoto \\ Student of Faculty of Public \\ Administration \\ Brawijaya University \\ Malang, Indonesia
}

\begin{abstract}
By providing adequate infrastructure facilities throughout Indonesia is expected to reduce poverty. Therefore, a substantial budget for infrastructure development is required. through data on infrastructure budgets in each district and city in Indonesia by 2015, this paper intends to see its relationship with poverty reduction by 2016. Using descriptive statistical analysis and will be displayed on the scatter plot. We found that the government budget for education, health, road infrastructure and the internet had a negative relationship. It means that increasing budget for infrastructure can reduce poverty rate. While, government budgets for electricity have a positive relationship. It means, raising the electricity budget can increase the poverty rate.
\end{abstract}

Keywords - infrastructure development budget; poverty reduction

\section{INTRODUCTION}

For the first time since 2015 Indonesia have increased the budget of infrastructure. The high budget for infrastructure development has become one of the main priorities which has been set in Jokowi's policy called NAWACITA with the aim of reducing poverty in Indonesia. Put special attention to infrastructure development such as road constructure, sanitation, access to clean water, bridges, and even access to education infrastructure, health and housing and settlements have been believed to help reduce poverty (Ali \&Pernia, 2003; Seetanah, Ramessur\&Rojid, 2009; Runsinarith, 2010).

Poverty is a situation where a person feels relatively lack of resources and or circumstances of their inability to utilize resources (Wilber, 1975; Townsend,1979). Every families and groups in the population can be said to be in poverty when they lack the resources to get food, not participate in activities and do not have the proper living conditions and facilities. While in Presidential Regulation Of Indonesia number 38 of 2015, defines infrastructure as a technical facility, physical, system, hardware and software facility that is needed to perform services to the people and support the network structure for the economic and social growth of the people to go well.

Infrastructure is devided into economic infrastructure and social infrastructure (World Bank,1994; Familion,2004). Economic infrastructure is a public means and infrastructure that provided by the government to the civil society such as electricity, telecommunications, roads and so forth. While social infrastructure leads to the improvement of facilities and infrastructure of education and health.

The poverty rate in Indonesia since 2010 has declined. The percentage of the poverty in 2010 was $13.33 \%$ and became $10.70 \%$ in 2016 (BPS, 2017). While the budget for infrastructure development in 2010 amounted to Rp 86 trillion to 2016 to $\mathrm{Rp} 317.1$ trillion (databoks, 2016). A budget is a key component of financial planning or financing for the future by identifying the goals and actions needed to be achieved (Hansen and Mowen, 2007: 316).

Fig. 1.patterns of poverty line and infrastructure budget in Indonesia

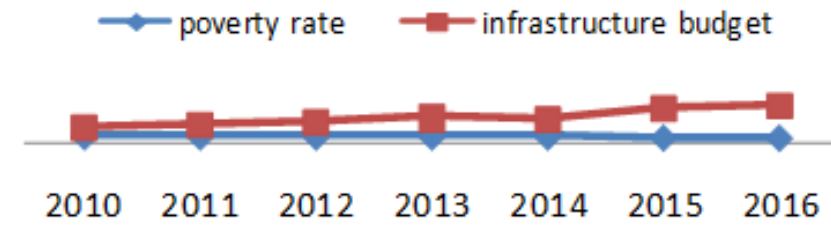

Based on fig.1, there is a line that is inversely related, Saparini (2008) says that in poverty alleviation needs a major attention to budget allocation. That is, what has happened in Indonesia so far, with the increase of budget allocation in infrastructure development also decrease poverty rate. This is in line what the World Bank (2004) said that in order to support the implementation of poverty reduction programs need to take several steps on infrastructure like upgrading of road and electricity facilities; improvement of health level; and then improving the quality of education.

Therefore, the purpose of this paper is to look at the relationship between infrastructure budgets on poverty alleviation in Indonesia. We use the 2015 budget data infrastructure aspects by the World Bank (1994) and Familion (2004), to see the achievement of poverty reduction in 2016 at districts and cities in Indonesia. Using descriptive substantial methods, which will be demnstrated through scatter plot analysis. 


\section{DISCUSSION}

\section{A. The Government Budget for Education}

The figure1 shows that there is a negative relationship between the education budget and the poverty rate. That if the government issued a high budget for education, it will have an impact on poverty reduction.

Education is one of the factors affecting the level of poverty. As expressed by the World Bank (2004) that in order to support the implementation of poverty reduction programs need to improve access to services education. It can be seen also as said by Kartasasmita (1996: 240) that the cause of poverty is because it has a low education so that the person does not have the skills, personal development and confidence. Jhinghan (2000) adds the cause of a person in a poor state due to lack of adequate infrastructure for education leading to a lot of people who are illiterate and have no skills.

The skills of the community will be useful for sebua state because of his ability to absorb modern technology and to build capacity so as to create growth and sustainable development (Todaro, 2004). Therefore, the role of government is needed in terms of educational investment. Because many people who do not get an education because of financial constraints owned. By investing in education will be able to improve the quality of human resources is shown by increasing their knowledge and skills. As (Iswara, 2014) suggests that higher levels of education will be an effect on the knowledge and expertise gained due to the low education has led to a person entered in poverty.

Fig. 2 correlation between education budget and percentage of poverty

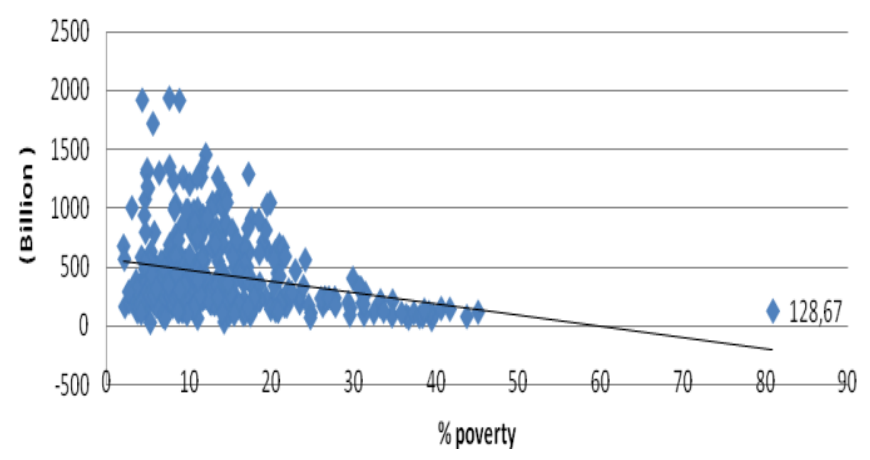

\section{B. The Government Budget for Health}

According to Law No. 36 of 2009 on Health, said that health is a healthy condition, both physically, mentally, spiritually and socially to enable more people to live socially and economically productive. Thus, health is of particular interest to everyone. Health is also a human right and one of the elements of prosperity be realized. Fig. 2 shows that both of the government budget for healt and the poverty rate have a negative relationship. If the government issued a high budget for health, it will have an impact on poverty reduction.
Plot health budget supports the theory of Kartasasmita (1996: 240) states that low health cause disease because of a lack of physical endurance so prone to poverty. Then Law Number 36 Year 2009 on Health that in case of health problems in the population of Indonesia, it would cause huge economic losses for the state supported the statement Lusted (2009: 12) that in caring for the poor in need of resources from the government is very large in health sector. Therefore, by increasing the health budget is expected to reduce poverty.

Likewise with Jhinghan (2000) who expressed a person's poverty due to poor health facilities and consumption patterns so that few people who become productive workers.Poor health levels are common in poor communities, where they do not have enough capital to maintain cleanliness and personal hygiene. Therefore, the government budget is indispensable in order to reduce the risk of death caused by poor health conditions. Some reasons for the increasing burden of disease experienced by the poor is as susceptible to the disease due to limited access to clean water and sanitation and adequate nutrition (Putri, Gunarto and ambya, 2015).

World Bank (2004) stated that in order to realize and support the implementation of the poverty reduction program, it would require one of which is the improvement of access to health services. Empirical studies are appropriate include Prasetya et al (2012) say that government spending on health is significantly affecting the number of poor people in rural areas. Then Fan, Hazell and Thorat (2000) studied in India and stated that any public expenditure on health infrastructure have an impact on poverty reduction. Every one million rupees are issued will increase to 18 poor people above the poverty line.

Fig. 3 correlation between health budget and percentage of poverty

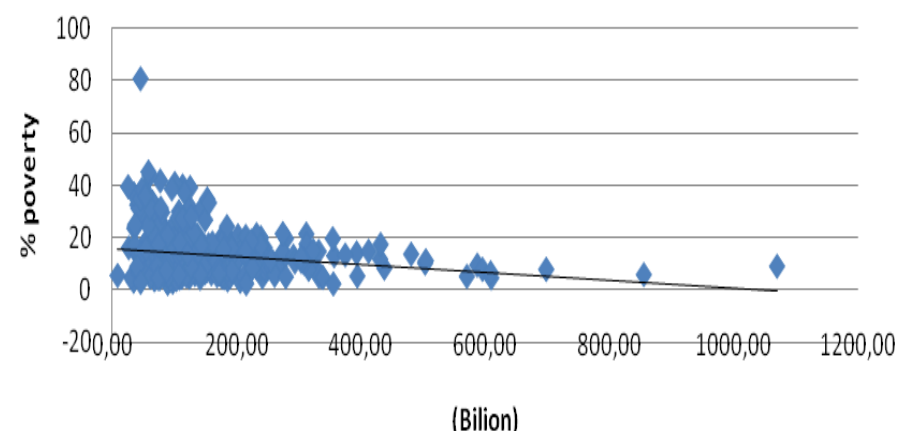

\section{The Government Budget for Road}

Road is the infrastructure that is needed to as ground transportation. The importance of a road is also associated with reductions in poverty. As expressed by Kartasasmita (1996: 240) that conditions such as living in isolated areas far from economic activities with the condition of the road infrastructure is inadequate cause the community to be in poverty because it is difficult to run or reach into the market economy. World Bank (2004) also gives the opinion that in supporting the implementation of poverty reduction programs need to perform several steps which include an increase in road facilities. 
Fig. 3 shows that there is a negative relationship between road infrastructure budget and percantage of poverty. if the budget for road infrastructure is greater, then it will reduce the poverty level. It is revealed the theory byHastuti (2016), that the greater the paved area (good / quality) then the opportunity for non-poor people in the region increases. Because of the access road has an important role in the economic, social, cultural, environmental, political, defense and security, as well as used for the welfare of the people. The road is also the distribution infrastructure of goods and services as the lifeblood of the community. So with the availability of access roads can easily cause people to perform activities and reach to the center of the economy, the smooth running of the productivity of goods and services and facilitate people reach their daily needs. Therefore, the budget on infrastructure development is needed in order to reduce poverty.

\section{The Government Budget for Telecommunication}

Road is the infrastructure that is needed to as ground transportation. The importance of a road is also associated with reductions in poverty. As expressed by Kartasasmita (1996: 240) that conditions such as living in isolated areas far from economic activities with the condition of the road infrastructure is inadequate cause the community to be in poverty because it is difficult to run or reach into the market economy. World Bank (2004) also gives the opinion that in supporting the implementation of poverty reduction programs need to perform several steps which include an increase in road facilities.

Fig. 4 shows that there is a negative relationship between internet budget and poverty reduction. It's mean that if telecommunication budget increased, then poverty will decrease.

Telecommunication networks are needed by everyone. When in a poor state, a person is under pressure. So what is really needed is the information network (Monge and Contractor, 2003: 237). This proves that the development for the provision of information technology facilities in every region in Indonesia must exist in order to reduce the poverty rate of Indonesia. Fan, Zhang, and Zhang (2002) in China, each government budgeted for increased access to telecommunications services by 10,000 yuan has raised 2.2 poor people into the poverty line. Such telecommunications proved to be a tool to combat poverty.It proves that development for the provision of telecommunication facilities in every region in Indonesia must exist in order to reduce poverty in Indonesia.
Fig. 4 correlation between internet budget and percentage of poverty

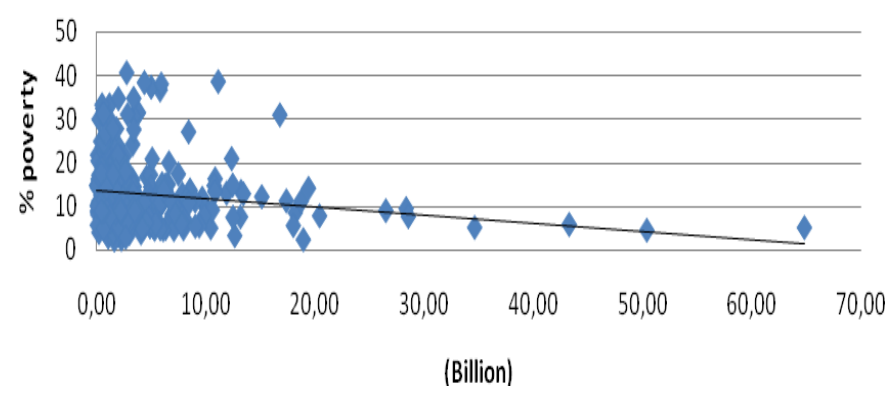

\section{E. The Government Budget for Electricity}

Electricity is a much-needed community facilities. None of the people who reject the existence of electricity, although there are still areas that until now still had electricity. Electricity became a very important need for the community, because every year the demand for electricity grew about 6 percent since 2000 (Indonesia Public Expenditure Review, 2007). Therefore, the budget of the electrical infrastructure is needed to meet electricity demand continues to rise. With the increase in electricity infrastructure budget is expected to reduce poverty in Indonesia. Hastuti (2016) says that the use of electric effect on poverty. Because electricity is used by the community as a means of lighting, so the chances of poor people not getting bigger because in carrying out their daily activities, people never escaped from the use of electricity.

However, the results shown fig. 5 refused that the high electricity budget would reduce poverty, although there is a relationship between electricity budget and poverty, but it is positive. Which means that when the budget is high then poverty is also high.However, not only limited to that. Through the deployment of which can be seen in fig. 5, a region that has a lower poverty levels get low budget. It could happen that the government did provide a high budget for the area which is a high poverty rate. As for in the area that low poverty level only given a low budget.

\section{CONCLUSION}

Looking at the relationship between infrastructure development budget and poverty reduction in Indonesia, it is expected that the result is negative. Because it indicates the high budget impact on the decline. However, in this paper, through five aspects of infrastructure used, 4 of which have a negative relationship. While the electricity budget has a positive relationship. This means that the high budget for electricity indicates the high number of poverty.

\section{References}

[1] Ali, I danPernia, E.M. 2003. Infrastructure and Poverty ReductionWhat is the Connection?, Philipppines: Asian Development Bank

[2] Databoks. 2016. Alokasi Anggaran Infrastruktur Dalam APBN 2010 2016, Online. Diakses melalui 
http://databoks.katadata.co.id/datapublish/2016/08/04/alokasi-anggaraninfrastruktur-dalam-apbn-2010-2016 pada 25 September 2017 pukul 20.00 WIB

[3] Familioni.K.A. 2004. The role of Economic and sosial infrastructure in economic Development, A Global View

[4] Fan, Shenggen, Peter Hazell, and Sukhadeo Thorat. 2000. "Government Spending, Growth and Poverty in Rural India." American Journal of Agriculture Economics, 82(2) : 1038-1051

[5] Fan, Shenggen, Lin Xiu Zhang, and Xiaobo Zhang. 2002. "Growth, Inequality and Poverty in Rural China : The Role Public Investment." EPTD Discussion Paper No. 66. Washington, D.C: International Food Policy Researc Institute.

[6] Hansen dan Mowen. 2007. Akuntansi Manajemen, Edisi 7 buku. Jakarta: Salemba Empat

[7] Hastuti, A. T. 2016. Analisis Kemiskinan dan Ketersediaan Infrastruktur di Pedesaan kawasan jalan lintas selatan jawa timur, Malang: Universitas Brawijaya

[8] Jhingan, ML. 2000. Ekonomi Pembangunan dan Perencanaan, Edisi Pertama. Raja Grafindo Persada. Jakarta.

[9] Kajian Pengeluaran Publik Indonesia. 2017. Online. Diaksek melalui http://siteresources.worldbank.org/INTINDONESIA/Resources/226271 1168333550999/PERFBAB5-Infrastruktur.pdf pada 25 September 2017 pukul 20.00 WIB

[10] Kartasasmita, G. 1996. Pembangunan Untuk Rakyat; Memadukan Pertumbuhan dan Pemerataan, Jakarta: CIDES
[11] Lusted, M.A. 2009. Poverty,Minnesota: ABDO publishing company

[12] Monge, P. R., dan Contractor, N. 2003. Theories of Communication Networks, Oxford: university Press

[13] Putri, R.M., Gunarto, T., dan Ambya. Jurnal Ekonomi. Pengaruh PNPM dan Alokasi Anggaran Belanja Daerah Untuk Pendidikan, Kesehatan dan Pekerjaan Umum Terhadap Kemiskinan di Provinsi Lampung, Vol.4, No1, April 2015. Unila Press

[14] Prasetya et al., 2012. Linkages Between Public Sector Expenditure On Economic Growth And Rural Poverty Of Indonesia. ISSN 2090-4304 Journal of Basic and Applied Scientific Research

[15] Todaro, Michael et,al. 2004. Pembangunan Ekonomi Dunia Ketiga. Jakarta: Erlangga

[16] Townsend, P. 1979. Poverty in the United Kingdom: A Survey of Househhold Resources and Standards of Living, Los Angeles: University of California Press

[17] Wilber, G. 1975. A New Pespective, Lexington: The University of Kentucky Press

[18] World Bank (2004) Indonesia Policy Briefs-ide-ide 100 hari, Mengurangi kemiskinan, diakses melalu http://siteresources.worldbank.org/INTINDONESIA/Resources/Publicat ion/280016

$1106130305439 / 6173311110769011447 / 8102961110769073153 /$ reduci ngpoverty.pdf.

[19] World Bank (1994. World Development Report: Infrasrtucture for Development. UK: Oxford University Press Inc 